\title{
Mircea Eliade and the Perception of the Sacred in the Profane: Intention, Reduction, and Cognitive Theory
}

\author{
BRYAN S. RENNIE \\ Westminster College
}

\begin{abstract}
Building upon earlier analysis of Eliade's 'sacred' as 'the intentional object of human experience that is apprehended as the real' (Rennie $1996,21)$ this article pursues the concept of the apprehension of the sacred in empirical experience as described by Eliade in his discussion of religious symbols. Using a variety of visual analogies an attempt is made to understand what Eliade's understanding might imply and how this 'perception of the sacred' might come about. This necessitates some consideration of the status of 'intentional objects' and leads to a reflection on Eliadean claims concerning the 'irreducibility' of religion and of the relation of such claims to contemporary cognitive analyses of religion. The conclusion is that Eliade's understanding can be seen as complementary to recent cognitive theory, which demonstrates the coherence of that understanding.
\end{abstract}

Keywords: Mircea Eliade, cognitivie theory, the sacred, religious symbols

In the second chapter of Reconstructing Eliade: Making Sense of Religion (Rennie 1996), I argued that Eliade's understanding of the sacred was as 'the intentional object of human experience which is apprehended as the real' (p. 21). That is, that Eliade's sacred is a phenomenological category. I will not rehearse here the details of my earlier argument, save to say that it was based on a close and extensive analysis of Eliade's work and was further supported by both J. Z. Smith's and William Paden's argument for the similarity of Eliade's understanding of the sacred with that of Émile Durkheim. I concluded that

J. Z. Smith [...] points out that Eliade may have substituted Rudolf Otto's language of the Holy for 'Durkheim's more neutral and positional sacred 
while maintaining the dynamics of Durkheim's dualism' (Smith 1978, 91) [and that] William Paden has demonstrated in more detail that the Eliadean category is 'under some debt to the French school' of Émile Durkheim. Here the sacred is 'an index of a system of behavior and representation which follows its own rules' rather than 'the name for the transcendent reality to which religious experience points and to which it responds'. (Rennie 1996, 21 quoting Paden 1994, also in Rennie 2006, 69. ${ }^{1}$ )

This reading of Eliade is still defensible. However, for the sake of precision some additional discussion is required. In his Logical Investigations Edmund Husserl speaks of 'intentional and true objects' (1970, 260. Vol. 2 Intro. §5). He talks of 'objectless ideas' (1970, 352. Vol. 2 Investigation II, Chapter two, $\S 7$ ), which he differentiates from 'ideal objects' (such as the number 2, the quality of redness, or the principle of contradiction) and which exist independently as the 'objects' of our ideas and are not 'mere fictions'. Speaking specifically of gods, Husserl says: 'If, however, the intended object exists, nothing becomes phenomenologically different. It makes no essential difference to an object presented and given to consciousness whether it exists, or is fictitious, or is perhaps completely absurd.' (1970, 559. Volume 2, V, §11.) In the same section, he calls intentions that lack intended objects 'merely intentional', and says further that 'we must distinguish between the object as it is intended and the object (period) which is intended' (1970, 578. Volume $2, \mathrm{~V}, \S 17)$.

If I represent God to myself, or an angel, or an intelligible thing-in-itself, or a physical thing or a round square etc., I mean the transcendent object named in each case, in other words my intentional object: it makes no difference whether this object exists or is imaginary or absurd. 'The object is merely intentional' does not, of course, mean that it exists, but only in an intention, of which it is a real (reelles) part, or that some shadow of it exists. It means rather that the intention, the reference to an object so qualified, exists, but not that the object does. If the intentional object exists, the intention, the reference does not exist alone, but the thing referred to exists also. (Husserl 1970, 596. Volume 2, V, Chapter two, §21, italics added).

So, to be perfectly faithful to Husserl's usage, it might be technically incorrect to refer to God or the sacred as an intentional object. That would assume

\footnotetext{
${ }^{1}$ Several of the works cited here have been anthologized in this last volume. I give page numbers of both the original publication and Rennie, 2006.
} 
the very conclusion that I sought to avoid. What I wanted to say was that the intention, the reference, exists. I defer judgment as to the existence of its object. After Husserl the Polish phenomenologist Roman Ingarden, Husserl's former student, developed the vocabulary of the 'purely intentional object', which is to say the intention that lacks an external object and which Husserl would call 'merely intentional', and the 'properly intentional object', which correspond most precisely to Husserl's extant intentional object. It was Ingarden's usage that I employed. In speaking of the sacred as an intentional object, I insisted that the question of its pure or proper intentionality was deferred (Rennie 1996, 21, 216).

We can of course question what aspects of any intention are 'merely' intentional. It seems unlikely that any intention, even one that does refer to a properly intentional object, relates perfectly to its object. It seems unavoidable that there will always be some aspect of the intention that is peculiar to the intention rather than derived from the intention relation. Unfortunately, this intention relation, like the correspondence relation in correspondence theories of truth, remains mysterious. Further, just as no intention can be entirely 'proper', we must ask whether any intention can be altogether 'merely intentional'. Husserl uses the example of the round square and the golden mountain; while these do not exist and therefore lack a proper intentional object, there are proper intentional objects for round, for square, for gold and for mountains. All we do is (imaginatively and creatively) to relate them; to construct (minimally) 'counterintuitive objects' in Pascal Boyer's phrase $(2001,65-78)$ that are purely intentional by conflating two properly intentional objects.

Despite this minor but important digression, it is still both correct and relevant to consider the sacred as 'intention' or as 'purely intentional object': that is, as an intentional reference of the human mind, leaving aside for the moment the question (properly addressed by metaphysics and theology) of the ontological status of its object. As Husserl says, 'this concept of consciousness can be seen in a purely phenomenological manner, i.e. a manner which cuts out all relation to empirically real existence' (1970, 537. Volume 2, V, Chapter One, §1; italics original).

Most importantly for present purposes, Eliade can be seen to leave aside the question of the putatively independent ontological status of the sacred in favor of a concentration upon observable human claims that some sacred or divine presence is apprehensible in the objects of veneration of the variety of religious traditions. As he repeatedly states, 'the sacred is an element in the structure of (human) consciousness' (Eliade 1969, i; 1977, 1; and 1978a, 
xiii). Understanding Eliade in this way requires an analysis of his equation of the sacred and the real such that 'the real' is also interpreted as an intentional object of human apprehension, a 'structure of consciousness', that may be more or less 'pure' or 'proper'. It might be argued that the sacred is not intersubjectively verifiable, and is therefore clearly not 'real' (not a properly intentional object). However, simply to identify the real with the empirically verifiable is an unacceptably narrow philosophical position that is not without problems; more to the point here, it was not the position that Eliade held. While there are a great number of empirically available entities that the majority of human agents can be relied upon to identify as 'real', there remains a correspondingly vast area of disagreement and of categories of dubious ontological status whose very existence indicates that 'reality' is also an intention that is held by human agents to be associated with some experiences and not with others.

For Eliade sacrality is a category that is apprehended by some people in some experiences while simultaneously remaining unrecognized by others in what is empirically the same experience. As he says,

à savoir qu'un miracle n'est évident que pour ceux qui sont préparés, par leur propre expérience et leur propre culture religieuse, à le reconnaître comme tel. Pour tous les autres, le 'miracle' n'est pas évident, il est donc inexistant; en effet il reste dissimulé dans les objets et dans les événements quotidiens. (Awareness of a miracle is only straightforward for those who are prepared by their personal experience and their religious background to recognize it as such. To others the 'miracle' is not evident, thus it does not exist; in fact it remains concealed in mundane objects and events.) (Eliade 1978b, 7.)

And further,

By manifesting the sacred, any object becomes something else, yet it continues to remain itself, for it continues to participate in its surrounding cosmic milieu. A sacred stone remains a stone; apparently (or, more precisely, from the profane point of view), nothing distinguishes it from all other stones. But for those to whom a stone reveals itself as sacred, its immediate reality is transmuted into a supernatural reality. (Eliade 1959b, 12.)

This reading of Eliade's understanding of the sacred has gone unchallenged and I suspect that it is irrefutable based on Eliade's actual statements. Nonetheless, it is simply ignored when his position is characterized as 
for example 'The Reality of the Sacred' (Pals 2005), with the philosophical complications of this equation lost in a simplistic identification of 'reality' with the empirically verifiable and ontologically independent, and the concomitant implication that Eliade assumed the sacred to be ontologically independent. Daniel Dennett likewise refers to Eliade's oft-quoted passage from Myth and Reality (1963) to the effect that 'a religious phenomenon will only be recognized as such if it is grasped at its own level [...] as something religious [anything else] misses the one unique and irreducible element in it - the element of the sacred' (Dennet 2006, 259; Eliade 1963, iii). Dennett identifies this position with 'those who insist that only those who believe, only those with a deep appreciation of the sacred, are to be entrusted with the investigation of religious phenomena' $(2006,261)$. Dennett considers this a 'preemptive disqualification' that is used to discredit rational analyses of religion, and again this is not an accurate representation of what Eliade has said. Eliade certainly does not 'persist in imagining God to be a Wise Old Guy in the Sky' as Dennett accuses 'the experts' of 'subtly encouraging' $(2006,266)$.

If 'the sacred' is seen as characteristic of certain intentional states, specifically the characteristic of manifesting reality, being, meaning, and truth, then one need not have any particular religious sentiment, but an understanding of religion as involving - by definition - that intentional affect. Dennett himself says, '[i]f you don't understand in some detail the enterprise of the people you are studying, you have scant chance of understanding their interactions and reactions at the human level. The same maxim should apply to the study of religious discourse and practices.' This is a better paraphrase of Eliade's position. It amounts to saying, as Dennett does, 'do your homework. [...] [Scholars] intent on explaining religious phenomena are going to have to delve deeply and conscientiously into the lore and practices, the texts and contexts, the daily lives and problems of the people they are studying'. (Dennett 2006, 313.) I could not agree more. While it is naïve to assume without question the existence of the sacred as an independent agent, it is equally naive to assume without question that Eliade's attribution of reality to the sacred is so unsophisticated. Equally naïve is the denial of all reality to the sacred since it unquestionably exists as the (pure?) intention of a definable area of human experience.

This recapitulation of the nature of the sacred for Eliade is a necessary introduction to my main theme, which is that of the perception of the sacred in the profane. Eliade clearly understood that homo religiosus, the religious agent or subject, in some way perceives the presence of the sacred in the 
objects of devotional traditions. His description of the sacred as at once the source of reality, being, meaning, and truth would seem to justify the identification of the sacred as the intention of a certain type of subjective experience (leaving aside the question of the purity or propriety of the intention). For example, 'every rite, every myth, every belief or divine figure reflects the experience of the sacred and hence implies the notion of being, of meaning, and of truth' (Eliade 1978a, xiii). From the early 1930s onwards Eliade made clear his understanding of all lived physical experience as not inherently meaningful. He perceived a human thirst to transform ordinary, run-of-the-mill experience into 'authentic' experience, expressive of the 'truly real', as common to both his Romanian intellectual friends and to the Indian Yogis and the popular devotees whom he had encountered in India. 'Normal, everyday experience is seen as illusory, unreal, profane [...] Yet that same experience, when apprehended in a specific way, when interpreted in a certain manner, becomes authentic, real, sacred: it becomes an hierophany.' (Rennie 1996, 10, 11. ${ }^{2}$ ) This is not without complexity. Considering Eliade's description of the sky as a hierophany of the transcendent from Patterns $(1958,39)$, I commented that

While it is true that we do not simply 'project' the qualities of infinitude and transcendence onto the sky it is misleading to assume then that we are simply given these concepts by our experience of the sky. Rather our experience of the world is a reciprocal affair. Without some pre-existent conception of infinitude we could never recognize the infinitude manifested to us by the sky. (Rennie 1996, 14.)

It is this reciprocal relation between the 'real' and its perception and understanding in and through religious symbols that I hope to clarify to some extent in this paper.

At a conference on 'Hermeneutics in History: Mircea Eliade, Joachim Wach, and the Science of Religions', at the Martin Marty Center for the study of religion at the University of Chicago Divinity School in November of 2006, I considered a series of consonances between Eastern Orthodox Christian theology and Eliade's thought indicative of the relation between the Romanian scholar and his native tradition. The Orthodox emphasis on mystical experience is paralleled by Eliade's emphasis on lived experience.

\footnotetext{
${ }^{2}$ For a detailed consideration of the route by which Eliade came to this conclusion see the whole of that chapter; it is also worthy of comment that 'profane' might be better understood as simply 'banal' or 'mundane' because it is not actively sacrilegious.
} 
The Orthodox veneration of icons closely resembles Eliade's notion of hierophany. Orthodox use of synthesis relates to Eliade's eclectic understanding of religion. The ritualism of Orthodox tradition echoes in Eliade's emphasis upon the 'transrational'. Orthodox theology agrees that '[o]nly one nature exists, common to all men, although it appears to us fragmented by sin, parceled out among many persons. [...] men possess a single common nature.' (Lossky 2001, 125.) This speaks to the universal human condition and shares that position with Eliade's humanism. Orthodox use of the language of the coincidence of opposites - 'to find reality, one must think being and non-being together [...] The living God must be evoked beyond the opposition of being and non-being, beyond all concepts' (Lossky 2001, 23) relates to Eliade's understanding of the coincidentia-oppositorum as transcending the material world. The Orthodox theologian Vladimir Lossky says that 'knowledge of divine nature is achieved and canceled out simultaneously in the impersonality of unknowing' $(2001,28)$, which is strongly reminiscent of Eliade's pervasive theme of the simultaneous revelation and camouflage of the sacred. Eliade's understanding of absolute freedom as the goal of all religious striving parallels the Orthodox concept of theosis. Finally, the 'narrative logic' and poesis of the Eastern Church seems to be the kind of logic that Eliade apprehended in all 'systems' of symbols and myths and which resonates in his 'creative hermeneutics' (see particularly Eliade 1961b). Lossky insists that only poetry can evoke the life of the hidden God; Eliade's creative hermeneutics is a poetic hermeneutics, an interpretation involving literary appreciation and narrative creativity.

I cannot attribute Eliade's understanding of religion entirely to Eastern Orthodox influence, since I am finally unable to argue with any confidence that Orthodoxy was the source of any specific components of Eliade's thought. For every possible Orthodox source of Eliade's theories there is also another potential source or an external corroboration. For example, Eliade's emphasis on experience as the source of salvific understanding could come from the mystical theology of the Eastern Church, but it is also found in the Protestant Italian historian of religions, Vittorio Macchioro, whom Eliade read, admired, and met in 1927 (Rennie 2007). The American Orthodox theologian and scholar Alexander Webster concluded that Orthodox theology 'need only allow for the primarily historical instead of mythical basis of Orthodox liturgical mysticism before adopting Eliade's approach to religion in its entirety' (Webster 1986, 642; in Rennie 2006, 410). But this is a very significant distinction from Eliade, who polemicized vigorously against historicism. That Eliade's thought can be used by Orthodox theology does 
not mean that it originated there. Webster recognized that 'Eliade [...] employed a metaphysical agnosticism in his writings', which contributes to the confirmation of my preceding analysis. Although this sacred 'leaves room for someone with more metaphysical certitude to objectify the "real" as the "numen" or "God"', according to Webster Eliade 'showed less concern for the nature of that sacred reality than for the attitudes and the behavior of the people who believe in it'. (1986, 636-637; Rennie 2006, 405.) It is significant that Webster, who studied Eliade carefully and who is himself committed to a theological stance, recognizes Eliade's focus on the attitudes and behavior of the people who believe in the sacred, rather than on the sacred per se, that is on the sacred as intention rather than as (properly) intentional object.

A passage by Eliade on the veneration of the lingam by Tribal peasant women (Eliade 1982, 54-60) has interesting implications. Mac Linscott Ricketts comments that Eliade 'seeing how the lingam [...] could evoke religious sentiments on the part of women and girls in India, [...] was able to understand the veneration of icons in Orthodox churches - something he had regarded previously as "idolatry"' (Ricketts 1988, 362). Despite his earlier support for Orthodoxy, Eliade had not actually sympathized until then with one of its most beloved and widely practiced rituals, the veneration of icons. It was Eliade's understanding of Hindu veneration that enabled his understanding of his own tradition. I suggest that this is an example of what I seek to explain about Eliade's understanding of religious symbolism: for Eliade the 'profane', or mundane experience of Orthodox worship, previously meaningless to him, is made meaningful by his experience of Indian devotion as seminal.

Both Eastern Orthodox and Hindu traditions provide examples of empirical experience as the source of an understanding that can 'save' or somehow transform the lot of the conscious human subject. The icon and the lingam, as mundane empirical perceptions (that is, to the majority of human subjects outside these specific traditions they are without transcendental referent or particular significance) are observably experienced as the location or revelation of the sacred to their worshipers. This observation is foundational to Eliade's thought. His understanding was that uninterpreted physical perception is without meaning - it is unreal, illusory, profane. It is, nonetheless, the only possible source of our perceptions of the real, the true, the meaningful - the 'sacred'. Thus the experience of the sacred is necessarily a simultaneous and paradoxical coincidence of opposite experiences.

Eliade came to this understanding relatively early in his life; being Romanian Orthodox, he had long been exposed to the Romanian church as a 
multi-media performative theater intent on inducing, via narrative, visual, and dramatic representations of elements of their tradition, transformative 'sacramental' experiences. This had not changed his own fundamentally 'modern' inability to perceive these representations as hierophanies. The journal of Eliade's Portuguese years 'is replete with explicit comments and affirmations that show Eliade to have been a man of definite convictions on many religious points [...] [although he] did not engage in conventional religious practices' (Ricketts 2006). In a fascinating attempt to derive Eliade's own religious beliefs from these statements, Ricketts reveals that Eliade in fact considered himself a 'pagan' unable to believe in Christianity, although he considered this to be a 'tragedy' (Ricketts 2006). Nonetheless, the Eastern Church could easily have sensitized the young Romanian to the potential of religious representation as an experience that can influence its audience so as to induce their apprehension of (that is, to 'reveal' to them) the 'real', 'the sacred' in their empirical experience. Both the orthodox icon and the Hindu lingam are apparently experienced by those who venerate them as something more than their experience gives to others - they are vehicles for the perception of the sacred. They are hierophanies.

Every effective and functioning religious symbol is a hierophany, a revelation of the sacred and it is in his analysis of symbols that Eliade is most specific about his understanding of the apprehension of the sacred. (Although of course what holds true for symbols also holds true for myths and rituals, since they are themselves systems of religious symbols in narrative or dramatic form.) Eliade's most precise exposition of symbolism occurs in an article of 1959, 'Methodological Remarks on the Study of Religious Symbolism' (also in Eliade 1965, 201-211, and Rennie 2006, 132-140). Here Eliade explains that

A symbol is not a replica of objective reality. It reveals something deeper and more fundamental. [...] Symbols are capable of revealing a modality of the real or a condition of the World which is not evident on the plane of immediate experience. [...] [L]et us take an example: the symbolism of the Waters, which is capable of revealing the pre-formal, the potential, the chaotic. This is not, of course, a matter of rational cognition, but of apprehension by the active consciousness prior to reflection. It is of such apprehensions that the World is made [...] it is not a question of considered knowledge, but of an immediate comprehension of the 'cipher' of the World. The World 'speaks' through the medium of the [symbol], and its 'word' is directly understood. (Eliade 1959a, 97-98; 1965, 201-202; Rennie 2006, 133.) 
Symbols allow people to 'become conscious' of alternative modalities of the real. They 'disclose to us a perspective from whence things appear different'. They 'make the immediate reality "shine"' (Eliade 1986, 6). In an explanation of 'The Structure and Morphology of the Sacred' from Patterns in Comparative Religion, Eliade argues that

this paradoxical coming-together of sacred and profane, being and nonbeing, absolute and relative, the eternal and the becoming, is what every hierophany, even the most elementary, reveals. [...] This coming-together of sacred and profane really produces a kind of breakthrough of the various levels of existence. It is implied in every hierophany whatever, for every hierophany shows, makes manifest, the coexistence of contradictory essences: sacred and profane, spirit and matter, eternal and non-eternal, and so on. [...] [T] he sacred may be seen under any sort of form, even the most alien. (Eliade 1958, 29; Rennie 2006, 54.)

The apprehension of certain physical perceptions, which as material perceptions are mundane and ordinary, as being authentically revelatory of a sacred reality that is simultaneously concealed and revealed within them is as we have seen characteristic of Eliade's understanding of religion. This is comparable to the optical effect of pattern recognition. When exposed to a confused or imprecise perception, in which the 'noise' overcomes the 'signal', we may not initially perceive the information contained in the experience. However, once a certain stimulus is supplied in the form of some semantic input, the signal overcomes the noise. Such an image - for instance of a cow - is usually not recognizable until the subject is told what it is. Then it becomes instantly and permanently meaningful. (See Figures 1a and 1b.)

This sort of conceptually determined or paradigm-determined perception is known as 'apperception', that is, a physical perception whose affect or significance is determined by prior experience and is thus experienced differently by differently prepared subjects. Thomas Kuhn argued in his Structure of Scientific Revolutions that even in the hard sciences 'paradigms determine large areas of experience' $(1962,129)$. Without appropriate prior conditioning experience some subjects will continue to be unaware of certain implications of their experience. That is, in specifically religious terms they will experience no apperception of the sacred meaning of otherwise mundane physical perceptions. As I quoted Eliade as saying above, '[a]wareness of a miracle is only straightforward for those who are prepared by their personal experience and their religious background to recognize it as such. To others 
the "miracle" is not evident, it does not exist.' (Eliade 1978b, 7.) Looked at in this way, religious myths, symbols, and rituals can be seen as deliberately constructed and communicable experiences, the aim of which is to transform our normal, mundane perception of the world into a perception (or more properly an apperception) of the sacred.

Eliade explicitly recognizes that in such cases 'the meaning is in the mind, as the phenomenologists would say', but adds that 'it is not a creation of the mind' (1973, 103 in Rennie 2006, 59; emphasis added). In order to explain further what I take Eliade to mean here, let me refer to certain other optical effects, specifically the well-known Kanisza figures (See Figures $2 \mathrm{a}$ and $2 \mathrm{~b}$ ).

The perception of the line is in the mind, but it is not solely a creation of the mind; it is strongly suggested by the data. These Kanisza objects demonstrate that it is often misleading to drive too firm a wedge between the experience and the interpretation of the experience, between the perception and the implication of the perception. However, as far as I am aware, all sighted human subjects perceive the dividing line between the inner and outer areas of the implied shapes (which do not exist as an external physical stimulus or a properly intentional object). By contrast, the implication of the religious symbol, the apprehension of the sacred, is not uniform or universal. Nor of course is it as simple as the optical effects that I have used to illustrate these ideas. When it comes to religious symbols there is no 'God's-eye view' from which to determine what is 'really' there. I would suggest that the operation of religious imagery is something like a combination of these two effects, in which 'personal experience and religious background' serves to condition the apperception of the sacred - so different people apprehend different things - but, like the Kanisza figures, what we seem to perceive is genuinely suggested by actual perception.

Eliade's analysis of symbols suggests that the apperception of the sacred is not arbitrary or delusory because it is based on our communal experience of the world and what that experience reveals to us. For example:

Before the discovery of agriculture, man did not grasp the religious meaning of vegetation. But with the discovery, man identified his destiny with the destiny of a plant; he translated the meaning of human existence into vegetative terms. As is the case with a plant, I am born from a seed, I will die, I will be buried, and I will come to life again. This meaning is certainly in the mind, yet it could not have developed before the discovery of agriculture. At the same time we cannot say that this religious intentionality of the vegeta- 
tion is a creation of the mind; it was already there in the fact that vegetative life starts from seeds, goes into flower and then dies and comes again. The intention is there and that intention is grasped by the human spirit, but it is not invented or created by the human mind because the intention is in the agricultural process. (Eliade 1973, 103; Rennie 2006, 59.)

This is emphasized in Eliade's article on the symbolism of the arrow, where he points out that ' $[n]$ o conquest of the material world was effected without a corresponding impact on human imagination and behavior' (1968, 465; Rennie 2006, 143). Similar to the discovery of agriculture, the discovery of the bow and arrow provided human cultures with images, effects, and relationships previously unthought-of. All new material technologies, like steam power and personal computing, make possible a range of symbolism that is not simply a creation of the mind but (like the lines in the Kanisza illusion) is strongly suggested by the data of empirical experience. The implicit meaning of the experience is not simply the same thing as the physical perception of the experience, but recognition of that meaning transforms the experience.

Eliade also adds that

an essential characteristic of religious symbolism is its multivalence, its capacity to express simultaneously several meanings the unity between which is not evident on the plane of immediate experience. The symbolism of the Moon, for example, reveals a connatural unity between the lunar rhythms, temporal becoming, the Waters, the growth of plants, women, death and resurrection (1959a, 99; Rennie 2006, 133),

and '[e]very hierophany we look at is also an historical fact. Every manifestation of the sacred takes place in some historical situation. Even the most personal and transcendent mystical experiences are affected by the age in which they occur.' (Eliade 1958, 2; Rennie 2006, 43.) Given this addition, it is necessary to add another layer of hopefully suggestive visual imagery to complete the explanation of Eliade's understanding of the perception of the sacred in the profane. Profane experience resembles an ambiguous (or, rather, polysemic, 'multivalent') image - Wittgenstein's Duck/Rabbit image is a famous example, but there are plenty of others (See Figures 3a and 3b).

Not only is there an ambiguity between the sacred or meaningful apperception and the profane or meaningless empirical perception, but there is also a multitude of potential interpretations of our empirical perceptions. The 
specific apperception of the sacred will be unavoidably shaped and colored by the historical situation in which it occurs because it does not empirically differ from the historical situation in which it occurs. However, the apperception of the sacred is always more than that historical situation and both remain perceptible (although not simultaneously by the same perceiving subject - once one has 'seen' the sacred - or the cow - the prior perception of the image as meaningless is different). For Eliade the hierophany is always an anamnesis, an unforgetting, because one does not actually 'see' anything 'new' but rather 'unforgets' the meaning of what was already there, as one recalls the duck/rabbit or the old man/peasant couple or suddenly realizes that the cow was there all along.

For Eliade, it seems, this is what the study of religion, as he defines it, is about - the (ap)perception of experiences as meaningful. This is in part why the religious cannot be reduced to the economic, the psychological, the political etc. These are specific strategies of meaning-recognition, specific ways in which the empirical data of physical perception and lived experience can be rendered more-or-less meaningful. They do not concern the general category of such recognition, the apperception of the sacred in the profane; thus they are not about the religious activity which (by definition for Eliade) centered on that apperception. To interpret Eliadean 'non-reduction' as insisting on the ontological autonomy of the sacred merely perpetuates and compounds the overly-simplistic reading of his understanding of the sacred and the real as mentioned earlier.

There is another way in which the study of religion might be seen as 'irreducible'. That is, it involves an unavoidably subjective component necessitating an aesthetic appreciation. Rodney Needham recognized that anthropologists cannot describe anyone's 'attitude to God, whether this was belief or anything else [...] it was one thing to report the received ideas to which a people subscribed, but it was quite another matter to say what was their inner state (belief for instance) when they expressed or entertained such ideas' (Needham 1972, 1-2). According to Dennett, this signals a 'need for recasting anthropological theories as accounts of religious behavior, not religious belief' $(2006,239)$. However, Dennett also recognizes that 'people need to see their lives as having meaning. The thirst for a quest, a goal, a meaning is unquenchable, and if we don't provide benign or at least nonmalignant avenues, we will always face toxic religions.' $(2006,334$.) So Dennett accepts the importance of meaning, and as an internal, individual, and non-intersubjective phenomenon meaning is not fully accessible to this recast and fully scientific theorizing. 
This understanding of the role of religion might be thought to unavoidably doom researchers in religion to inescapably fruitless speculation about the content of other people's minds (or specifically their 'pisteuma' as Raimon Panikkar (1989) has called it - the content of people's faith-based apprehensions). Happily, this is not the case. Just as 'behaviorists were meticulous about avoiding speculation about what was going on in my mind or your mind, or his or her or its mind' (Dennett 1991, 70), so the phenomenologist can be likewise meticulous. Dennett explains that minds 'are not among the data of science, but this does not mean that we cannot study them scientifically $[\ldots]$. The challenge is to construct a theory of mental events, using the data that scientific method permits.' $(1991,71$.) He calls this 'heterophenomenology' and describes it as 'a method of phenomenological description that can (in principle) do justice to the most private and ineffable subjective experiences, while never abandoning the methodological scruples of science' (Dennett 1991, 72). This method 'makes no assumption about the actual consciousness of any apparently normal adult human beings' $(1991,73)$. Dennett goes on to consider the role of verbal interactions in empirical psychological or neurological studies. In, for example, preparing a written transcript of some such experiment from an audio record, we are interested in the sounds 'that are apparently amenable to a linguistic or semantic analysis' (Dennett 1991, 74; italics original). In so doing, he points out, 'we move $[\ldots]$ from one world - the world of mere physical sounds - into another: the world of words and meanings' $(1991,74)$. I would argue that, in Eliade's terms, this is equivalent to a move from the profane to the sacred. This 'yields a radical reconstrual of the data' (Dennett 1991, 75) and Dennett asks, '[w] hat governs this reconstrual?' (1991, 75.) Obviously, in Dennett's example, 'it depends on assumptions about which language is being spoken' (1991, 75). It is based upon such assumptions that the raw data of physical sounds can be 'purified' into formal expressions and we can '"make sense" of the sound stream in the process of turning it into words' (1991, 75). As I argued in Reconstructing Eliade, the history of religion is a process of making sense of the raw data of our observation of religious phenomena in the same way as I attempted to 'make sense' of the texts of Eliade, and that religion itself is a comparable process of making sense of the world of our lived experience (Rennie 1996, 1-6). A large part of the process involved, as Dennett insists, is amenable to a linguistic or semantic analysis. However, I would argue that it cannot be reduced to this analysis without remainder. 
Dennett recognizes that such 'making sense' is not final; that is, it does not necessarily 'proceed all the way to understanding' $(1991,76)$. The linguistic process might stop at word recognition with no understanding of the further implication of those words. However, even in that case 'we must move beyond the text' $(1991,76)$ as a purely physical entity. Where Dennett is more precise that we must interpret the empirical text as 'a record of speech acts' $(1996,76)$ Eliade spoke more vaguely of the meaning of the religious text (see the subject index in Rennie 2006 for Eliadean references to meaning). 'We must treat', says Dennett, 'the noise-emitter as an agent [...] who harbors beliefs and desires and other mental states that exhibit intentionality [...] and whose actions can be explained [...] uttered noises are to be interpreted as things the subjects wanted to say [...] meant to assert' $(1991,76)$. No matter how detailed our clinical investigations of religion may become, there will always be a remainder that concerns this 'meaning' and that involves the speculative reconstruction of this inaccessible, subjective, intentional state.

It would not be surprising to consider at this point some more complex version of Fredrich Max Müller's assertion that religion is a disease of language (see for example Sharpe 1975, 40-43). Since human agents are so accustomed and indeed neurologically programmed to make sense out of language, we are misled into assuming that non-linguistic aspects of our experience likewise 'make sense'. However, I am more inclined to think that Eliade saw it as a more-or-less unavoidable concomitant of language-using consciousness that had potentially beneficial consequences. This would certainly be consonant with his frequent assertions that religion is a human universal. As he says:

If, in the history of religions, the idea of the sacred is related to the idea of being and meaning, the historian of religions - who is also a phenomenologist because of his concern with meaning - will eventually discover something which has not always been evident: that the sacred is an element in the structure of human consciousness. [...] [M]an simply discovers himself in the world, that the structure of his consciousness is such that somewhere in his experience there is something absolutely real and meaningful, something that is a source of value for him. As far as I understand it, the structure of human consciousness is such that man cannot live without looking for being and meaning. If the sacred means being, the real, and the meaningful, as I hold it does, then the sacred is a part of the structure of human consciousness. (Eliade 1973, 101 in Rennie 2006, 58.) 
Again Eliade can be seen to agree with Dennett's approach to the extent that both attempt to 'get at what these people are experiencing' (Dennett 1991, 78). Of course, Dennett continues - and I agree - '[w]e can't be sure that the speech acts we observe express real beliefs about actual experiences; perhaps they express only apparent beliefs about nonexistent experiences' $(1991,78)$. However, certitude is not required. As Dennett says, ' $[\mathrm{w}] \mathrm{e}$ can compare the heterophenomenologist's task of interpreting the subject's behavior to the reader's task of interpreting a work of fiction' (Dennett 1991, 79). Similarly, Eliade held that 'it is regrettable that historians of religion have not yet sufficiently profited from the experience of their colleagues who are historians of literature or literary critics' (Eliade 1969, 4). So he too was conscious of the confluence of literary and phenomenological analysis. Of course, works of fiction only weakly imply the ontological independence of their characters, whereas the autonomy of their characters is strongly asserted by religious texts and their adherents. A focus on the human origins and literary form of the religious text apparently reduces its ability to work its transformative effect. This does not change the role of the heterophenomenologist, whose task is to interpret both. The heterophenomenologist 'lets the subject's text constitute that subject's heterophenomenological world, a world determined by fiat by the text. [...] The subject's heterophenomenological world will be a stable, intersubjectively confirmable theoretical posit.' (Dennett 1991, 81.) The text here is not only the sacred ritual or scripture that inspires the believer (although it involves that), but is the record of the believers' statements concerning their subjective experiences.

Dennett considers the hypothetical case of certain 'anthropologists who were to discover a tribe that believed in a hitherto-unheard-of god of the forest called Feenoman. [...] Feenoman is being treated as merely an "intentional object", a mere fiction so far as the infidels are concerned' (1991, 82). However, the 'heterophenomenological method neither challenges nor accepts as entirely true the assertions of subjects, but rather maintains a constructive and sympathetic neutrality, in the hopes of compiling a definitive description of the world according to the subjects' (Dennett 1991, 83). The subjects may of course insist not only that the objects of their assertions really do exist as autonomous entities but also that this is a point of crucial importance. Again, that may contribute to but does not fundamentally change the heterophenomenological undertaking to describe the subjective world of the subject and to thus access its meaning.

The point of this digression into the work of Daniel Dennett is that despite the criticism of Eliade's insistence that religion is a meaningful, irreducible, 
sui generis phenomenon, none of the foregoing analysis of Eliade's thought fundamentally contradicts the observations of the most recent reductionist theorizing in the academy, the cognitive science of religion. This approach generally tries to provide an evolutionary explanation of religion in terms of its contribution to human survival and reproduction. There are two main positions within this approach: one of them argues that religion itself is an evolutionary adaptation, that is, that it contributes positively to survival and reproduction, while the other argues that on the contrary religion is merely a side-effect of other evolutionary adaptations and has in and of itself nothing contributory to offer. On the contrary, it may even be negative.

Despite disagreements over the adaptive or merely coincidental status of religious behavior, all cognitive theorists agree that religion is in part produced by cognitive tools or mental 'modules' devoted to specific tasks. Particularly active in this respect is the module devoted to the recognition of the presence of agents (the so-called 'agency detection device'); another the module for producing causal narratives describing the events of the natural world in comprehensible and predictable terms ('causal reasoning'); and a third the one for recognizing that other agents are possessed of minds similar to one's own but with their own beliefs, desires, and intentions (called variously 'theory of mind', 'folk psychology', 'agency describer', and by Dennett, 'the intentional stance', 2006, 108). The agency detection device is adaptive because assuming the presence of a potentially dangerous agent is more conducive to survival than assuming its absence or failing to register its presence. This tendency to ascribe agency to our perceptions primes us, so to speak, for religion. Causal reasoning does likewise. We habitually look for narrative explanations of events, and where none are forthcoming we supply our own. Supernatural agents provide excellent dei-ex-machina to suit that purpose. Where no other rational explanation can describe events, our causal reasoning module is more comfortable with some explanation, no matter how imaginative, than with none. Lastly, the intentional stance allows us to anticipate and influence others' behavior - and it also enables us to think about disembodied agents.

Dennett's 2006 volume, Breaking the Spell, concentrates entirely on the cognitive study of religion. Its principal thesis is that empirical and clinical observations and experimentations can be performed to evaluate whether or not religious behavior is genuinely adaptive, i.e. contributory to human reproduction and survival. This raises a host of questions as to whether human reproduction and survival is necessarily the highest possible goal and value. This, I would contend, is the same question of the ontological status 
and autonomy of the sacred as intentional object returning in a slightly different form: would 'the sacred' exist independently of any human mind in which it is instantiated as an intention? Is the sacred more important than the human minds by which it is intended? Once again, I must follow Eliade in leaving that question to the metaphysician and theologian.

There is little doubt that Eliade considered religion to be desirable, even though Ricketts (2006) has shown that personal commitment seems to have been beyond him. Eliade's analysis, as I have interpreted it, would allow that while specific religious traditions might be non-adaptive 'byproducts', religious behavior in its most general sense is adaptive. It was in this most general sense that William James defined religion as 'the belief that there is an unseen order and that our supreme good lies in harmoniously adjusting ourselves thereto' $(1971,69)$. In this most general sense, the apperception of the sacred would be the apprehension of some 'order', specifically some order to which we can 'harmoniously adjust' our behavior to our own ultimate benefit, and this may be seen as self-evidently adaptive. The religious symbols (myths and rituals etc.) of specific traditions can be seen as attempts to communicate experiences conducive to apperceptions of that order. This undoubtedly leads to byproducts specific to local cultures, that may be - as Dennett describes them - mutualist, commensal, or parasitic $(2006,84)$; that is beneficial, neutral, or even harmful. However, the general apperception in our complex and necessarily incomplete experience of an orderly whole, to which we can coherently and consistently respond, makes a strong claim to being adaptive, since it permits a consistent, coherent, and at least partially predictable response. It is at least homologous to our ability to perceive the orderly, rule-governed, nature of human language. (This latter is of course a kind of apperception, since it requires a considerable amount of preparatory experience to have this perception. One cannot simply perceive the order in any and every language.)

It is conceivable that clinical tests and empirical studies could be designed to investigate the adaptivity of a 'module' of the human mind that seeks consistent order in experience. Such a module would no doubt be closely connected to the 'causal reasoning' module. It might, indeed be more or less identical to it. It is interesting to note that Eliade comments in his journals on the 'exile returning to Ithaca', who represents all of humanity in our 'search for the center'. It is better, he says, to recognize meanings and see signs even if they are not there $(1977,58$ - Eliade expounds on this theme further in his short story, 'Incognito la Buchenwald' 1980), in which his characters are forced to 'interpret' meaningless water stains on a wall. Although this 
raised the ire of for example Ivan Strenski (1982, 392ff.) as an example of the deliberate proliferation of non-existent entities, perhaps, if it is read as an existential need to (ap)perceive some zusammenhang to our experience rather than none, it becomes more comprehensible and acceptable.

It is not my claim that Eliade somehow anticipated cognitive theories of religion. Rather I simply seek to show that his understanding is not undermined by such theorizing, but is, on the contrary, complementary to it and cognitive theory bears witness to the coherence of Eliade's position. I would argue that, in Eliade's understanding, religious symbols, myths, and rituals may not themselves be historically accurate or physically veridical and so they might appear to be inaccurate misunderstandings and misrepresentations of the world. This might make them appear to be anything but positive adaptations. However, as he said, 'a symbol is not a replica of objective reality [but] reveals something deeper and more fundamental'. Symbols. Myths, and rituals constitute, rather, physical perceptions and experiences that 'fine tune' our apperception of the world encouraging the recognition of a consistency and coherence to which we can conform our behavior. This image is taken from Wassily Kandinsky's Über das Geistige in der Kunst (1911) where he says that, 'die "Stimmung" des Werkes kann die Stimmung des Zuschauers noch vertiefen - und verklären. Jedenfalls halten solche Werke die Seele von der Vergröberung ab. Sie erhalten sie auf einer gewissen Höhe, wie der Stimmschlüssel die Saiten eines Instrumentes.' "The mood [literally "voice" - the way it speaks to one] of the work [of art] can deepen - and clarify - the mood of its audience. At least such works of art stop the soul from coarsening. They tune it to a certain pitch, as the tuning-key does the strings of an instrument.' (Kandinsky 1911, 5.) Religious symbols can be seen as catalytic 'seminal experiences' that enable the recognition of a meaning in ensuing experience, just as the word 'cow' enables our recognition of the content of the confused image, or as Eliade's experience of Hindu devotees 'fertilized' his understanding of Eastern Orthodox devotions. This also constitutes a significant contribution to our understanding of the relationship of religion and art. Religious art particularly and explicitly uses traditional forms to enable and encourage the apperception of the sacred in mundane experience.

It does not require a great deal of imagination to understand the evolutionary contribution of perceiving (or apperceiving) human experience as having some meaning as opposed to none, as having some coherent and consistent response to the human situation as opposed to none, and as having some potential resolution to the human dilemma. Eliade's understand- 
ing of religious symbolism goes some way towards suggesting how such imaginary, or at least imaginative, responses to our environment might be 'true' in the sense of workable adaptations to the human condition, even if their historical accuracy or physical factuality is unverifiable or even obviously false. He consistently stresses the imaginary as effective. As we have already seen, he insists that 'no conquest of the material world was effected without a corresponding impact on human imagination and behavior', and he adds to that, 'I am inclined to add that the reflections of the objective conquests upon such imaginary Universes are perhaps even more important for an understanding of man' (Eliade 1968, 465, in Rennie 2006, 143). In The Quest (1969) he points out that initiatory motifs and symbols 'partake of an imaginary universe, and this universe is no less important for human existence than the world of everyday life' (Eliade 1969, 121). And in Images and Symbols (1961a): 'that essential and indescribable part of man that is called imagination dwells in realms of symbolism and still lives upon archaic myths and theologies' (Eliade 1961a, 19). On a slightly different note, which serves further to explain his meaning, he states that 'the novel must tell something, because narrative (that is, literary invention) enriches the world no more and no less than history, although on another level' (Eliade 1977, 205).

That imagination is not only of great importance but also an integral part of religious life is indicated by Eliade's statement that '[o]ne can pass through a the Symplegades in so far as one behaves "as a spirit", that is to say shows imagination and intelligence and so proves oneself capable of detaching oneself from immediate reality' (Eliade 1959a, 101 in Rennie 2006, 135). This identifies 'spiritual' existence with imagination and, specifically, with the ability to 'detach oneself from immediate reality'. For Eliade, 'spiritual' existence is constituted by the specific human imaginative ability to become detached from immediately experienced reality, Erlebnis, or 'history'. This is his 'escape from history', nothing more (or less) mystical than the ability to learn from that which one has not oneself experienced and, via 'spiritual' discipline, to avoid the purely physical effects of causal determination and to see the world as something other, something more, than merely the sum of physical perceptions. At one extreme this might possibly enable astonishing feats, like sitting naked on a glacier for days, at the other it is simply not allowing the quotidian pressures of life to 'get you down' (which, given human psychology, may ultimately be no less astonishing a feat). One 'escapes from history' every time one smiles in the face of adversity or performs any act that is not directly determined by historical/empirical preconditions (such as making any sacrifice). This can most effectively be 
accomplished with reference to the object of religious belief - the sacred - as apperceived in and through the mundane world as transformed by religious myth, symbol, or ritual. When one actually experiences the world as infused with meaning; possessed of a compelling causal narrative; one can react to it with more confidence, control, and consistency.

Our ability to 'escape history' in this way is directly dependent on our relationship to imaginative narrative. One illustration that I have already employed to explain this was taken from Martin Seligman's 1975 book, Helplessness (Rennie 1996, 223-224). 'Helplessness' is the condition in which an experimental subject acquiesces and no longer makes any attempt to avoid 'powerful negative stimuli' (suffering). This condition is induced relatively easily in subjects who (or which) have no way to control the suffering. Given some measure of control, subjects are considerably more resistant to such 'helplessness' (this applies to a large range of animals as well as to people) but continue to strive for an improvement of its condition, no matter how elusive control may be. In an empirically controlled experiment Seligman reports that 'merely telling a human subject about controllability duplicates the effects of actual controllability' $(1975,48)$. In other words, a story which one is told can have the same effect as if it were a part of the world of real experience (and Seligman is quite clear that it does not have to be 'true' in the sense that it does not have to be factual or historically accurate). Stories, as stories, are in fact part of the world of intentional experience. By dint of imagination and the apperception of the sacred in the profane the human spirit can be seen to 'escape history', to be 'detached from the immediate reality', 'to be 'autonomous' in that it is not wholly determined by its physical environment but contributes, through the imaginative generation of narrative, to the construction of its own determining environment. Imaginative narrative creations of the human mind become a component part of the conditioning factors in human experience, and one which history reveals to be of the greatest significance. Significance is not an inherent characteristic of objects or events, but is a creation of human interpretation.

Even as a concept, an imaginative fiction in the sense indicated here, an intention, religious concepts, such as 'God', are infinitely creative entities, beings of unbounded imaginative fertility, capable of supporting a wealth of imaginary universes. Once the idea of God has been conceived, it is eminently possible to conceive for example the idea of heaven, paradise, etc; that is to say a mode of being in which humanity is not conditioned or limited by our actual, physical, and moral state. It can quite credibly be suggested that if one cannot imagine an eternal and perfect state of human 
existence, then one cannot have really imagined, or imaginatively realized, the idea of God.

To those who insist on the self-evident nature of the empirical and perceptible as the real, Eliade's equation of the sacred and the real is simply wrong, as is his insistence that the religious cannot be reduced to any other area of human analysis, and the creative hermeneutics of Eliade's history of religions will remain an unwarranted proliferation of imaginary non-entities. The meaninglessness of 'religion' for this particular group, however, cannot render religion meaningless for others. The characterization of religion as the mere proliferation of imaginary non-entities corresponds to the deliberate restriction of imagination, a denial of meaning, a refusal of creativity, and little else. If it be accepted that the creative imagination has an effective role in inducing specific apperceptions then symbols, as creative, meaningful, pre-reflective devices, are not just symbols but also effective tools for controlling or tuning perception. If one recognizes that imaginary ideas have real effects then the restriction of an idea capable of infinite effects to the imaginary is finally no restriction at all.

Studies have indicated that for example religious kibbutzim behaved more co-operatively than their secular counterparts and that the distinction was greatest with those men who attended synagogue daily (see Sosis \& Ruffle 2003a; 2003b). The authors of that study suggest that it is the public display of devotion that effects this distinction. Eliade's thought suggests that those who attend religious ritual more frequently will be more effectively conditioned by that ritual to (ap)perceive their world as being possessed of an order in which co-operative, obedient, self-sacrificing, and 'righteous' behavior is more certainly rewarding. Their experience of the world, conditioned by religious myths, symbols, and rituals, is an apperception of the profane as suffused by the sacred and possessed of a predictable and reliable (and benevolent) structure. Just as the word ' ${ }^{\circ} \mathrm{w}^{\prime}$ ' allows us to recognize the image of the cow and transforms an apparently meaningless chaos of shapes into a meaningful constellation, so religious traditions can stimulate their audience to apprehend the world in which they live as a meaningful event to which the appropriate response is co-operation and altruism. In this way, in Eliade's words, it can 'make the immediate reality "shine"' (Eliade 1986, 6).

If such an understanding of religion be adopted, what implications might this have for its study? Nothing massively far-reaching. The study will go on much as before, with ethnography and philology leading the way, but for methodologists and theorists there may be some fruitful implications. 
I agree with Dennett that empirical and clinical studies can and should be performed to distinguish the 'mutualist' from the 'parasitic' elements of religious traditions. However, it is implied that there is also a complementary component to the study of religion that will remain for the foreseeable future irreducibly subjective or aesthetic, more akin to literary and artistic criticism than to any clinical procedure.

\section{Bibliography}

\section{Boyer, Pascal}

2001 Consciousness Explained: The Evolutionary Origins of Religious Thought. New York: Basic Books.

\section{Dennett, Daniel}

1991 Consciousness Explained. London \& Boston: Little, Brown, and Company.

2006 Breaking the Spell. New York: Viking.

\section{Eliade, Mircea}

1958 Patterns in Comparative Religion. London: Sheed and Ward.

1959a Methodological Remarks on the Study of Religious Symbolism. - Mircea Eliade \& Joseph Kitagawa (eds), History of Religions: Problems of Methodology, 86-107. Chicago: Chicago University Press.

1959b The Sacred and the Profane: The Nature of Religion. London: Harcourt Brace Jovanovich.

1961a Images and Symbols: Studies in Religious Symbolism. London: Harvill Press.

1961b The History of Religions and a New Humanism. - History of Religions 1, 7-8. [Also appears as 1969, ch.1.]

1963 Myth and Reality. New York: Harper and Row.

1965 The Two and the One. Chicago: University of Chicago Press.

1968 Notes on the Symbolism of the Arrow. - J. Neusner (ed.), Religions in Antiquity, 463-475. Leiden: E. J. Brill.

1969 The Quest: History and Meaning in Religion. London: University of Chicago Press.

1973 The Sacred in the Secular World. - Cultural Hermeneutics 1, 101-113. [Also appears in Rennie, 2006, 57-67.]

1977 No Souvenirs: Journal, 1957-1969. New York: Harper and Row. [Also published as Journal II, 1957-1969. Chicago, University of Chicago Press, 1989.]

1978a A History of Religious Ideas. Vol. I. From the Stone Age to the Eleusinian Mysteries. Chicago: University of Chicago Press.

1978b Mademoiselle Christina. Paris: L'Herne.

1980 Incognito la Buchewald. - Eugen Simion (ed.), In Curte La Dionis: nuvele fantastice. Bucharest: Cartea Românească. [Unpublished English translation, 'Incognito in Buchenwald', by Mac Linscott Ricketts.] 
1982 Ordeal by Labyrinth: conversations with Claude-Henri Rocquet. Chicago: Chicago University Press.

1986 The Symbolism of Shadows in Archaic Religions. - Diane ApostolosCappadona (ed.), Symbolism, the Sacred, and the Arts, 3-16. New York: Crossroad.

\section{Husserl, Edmund}

1970 Logical Investigations. New York: Humanities Press.

\section{James, William}

1971 (1902) The Varieties of Religious Experience. Great Britain: Collins/Fontana.

\section{Kandinsky, Wassily}

1911 Über das Geistige in der Kunst. Munich: R. Piper and Co.

\section{Kuhn, Thomas}

1962 The Structure of Scientific Revolutions. Chicago: Chicago University Press.

\section{Lossky, Vladimir}

2001 Orthodox Theology: An Introduction. Crestwood, NY: St. Vladimir's Seminary Press.

\section{Needham, Rodney}

1972 Belief, Language, and Experience. Chicago: University of Chicago Press.

\section{Paden, William}

1994 Before 'The Sacred' Became Theological: Rereading The Durkheimian Legacy. - Thomas A. Idinopulos and Edward Yonan (eds), Religion and Reductionism: Essays on Eliade, Segal, and the Challenge of the Social Sciences for the Study of Religion, 198-210. Leiden: E. J. Brill. [Also appears in Rennie, 2006, 68-80.]

\section{Pals, Daniel}

2005 Eight Theories of Religion. New York: Oxford University Press. [First published as Seven Theories of Religion in 1996.]

\section{Panikkar, Raimundo}

1989 Personal Conversation following the Gifford Lectures. Edinburgh.

\section{Rennie, Bryan S.}

1996 Reconstructing Eliade: Making Sense of Religion. Albany, N.Y.: The State University of New York Press.

2006 Mircea Eliade: A Critical Reader. London and Boston: Equinox Publishing.

2007 The Influence of Eastern Orthodox Christian Theology on Mircea Eliade's Understanding of Religion. - Wendy Doniger \& Christian 
Wedemeyer (eds), Hermeneutics in History: Mircea Eliade, Joachim Wach, and the Science of Religions. Oxford University Press (forthcoming).

\section{Ricketts, Mac Linscott}

1988 Mircea Eliade: the Romanian Roots. Vols. I \& II. New York: Columbia University Press.

2006 'Eliade's Religious Beliefs as Shown in the Portuguese Journal.' Unpublished paper read at the 6th EASR and IAHR Special Conference, Bucharest, September 20-23.

\section{Seligman, Martin E. P.}

1975 Helplessness. San Francisco: Freeman and Co.

\section{Sharpe, Eric J.}

1975 Comparative Religion: A History. La Salle, IL: Open Court.

\section{Smith, Jonathan Z.}

1978 Map is not Territory. Leiden: E. J. Brill.

\section{Sosis, Richard \& Bradley Ruffle}

2003a Religious Ritual and Cooperation: Testing for a Relationship on Israeli Religious and Secular Kibbutzim. - Current Anthropology 44, 713-722.

2003b Does It Pay To Pray? Evaluating the Economic Return to Religious Ritual. - The B. E. Journal of Economic Analysis and Policy 7, 1-35. [Also available at http://ideas.repec.org/p/wpa/wuwpex/0309002.html.]

\section{Strenski, Ivan}

1982 Love and Anarchy in Romania. - Religion 12(4), 391-404.

Webster, Alexander F. C.

1986 Orthodox Mystical Tradition and the Comparative Study of Religion: An Experimental Synthesis. - Journal of Ecumenical Studies 23, 621-649. [Also appears in Rennie 2006, 404-410.] 


\section{Appendix: Figures}

Figures 1a and 1b. A cow and a Dalmatian dog sniffing among fallen leaves. Such images are usually not recognizable until the subject is told what they are. Then they become instantly and permanently meaningful.

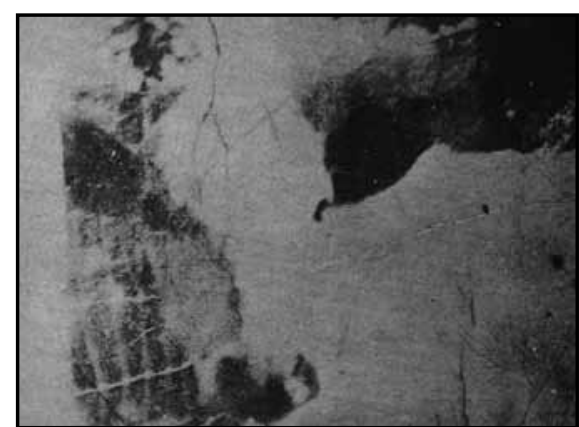

http://www.squarefree.com/2004/01/22/91/

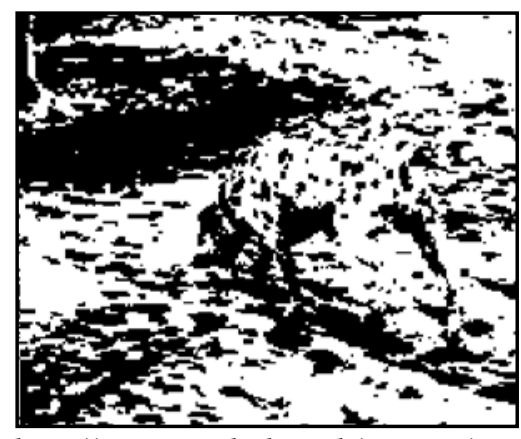

http://www.pc.rhul.ac.uk/courses/ Lectures/PS1061/L10/PS1061_10.htm

Figures 2a and 2b. Kanisza Figures, in which the suggested shape is strongly perceived by the subject although not empirically present to the senses.

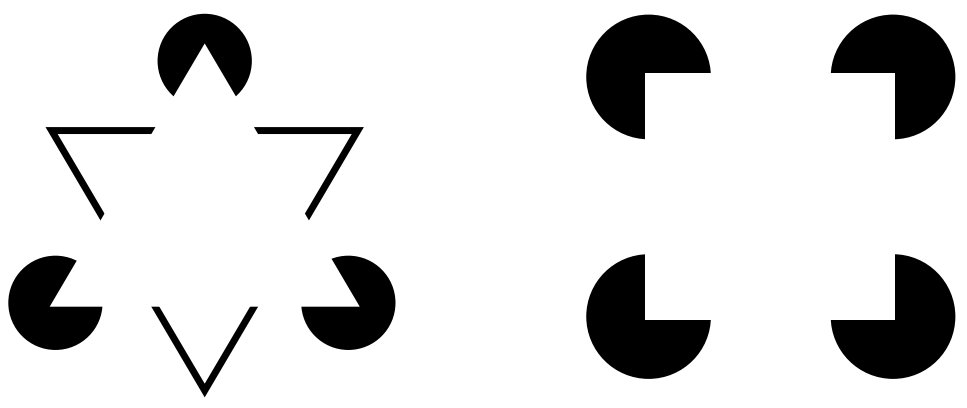

Figure 3a and $3 \mathbf{b}$. Like ambiguous or polysemic images, the religious symbol is multivalent and more than one meaning can be seen in the 'profane' or empirical experience.
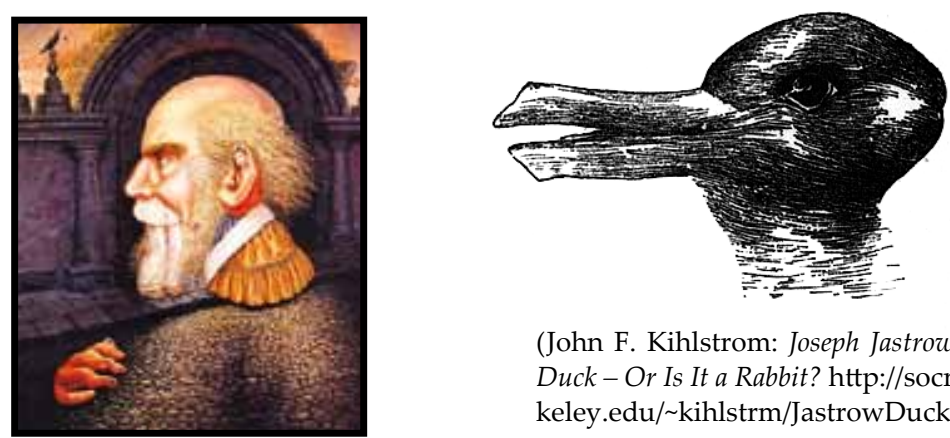

(John F. Kihlstrom: Joseph Jastrow and His Duck - Or Is It a Rabbit? http://socrates.berkeley.edu/ kihlstrm/JastrowDuck.htm)

Octavio Ocampo: General's Family.

http:/www.grand-illusions.com/opticalillusions/ocampo/ 